\title{
Fluvial history of the Vecht-Amstel area in the Holocene: Interdisciplinary collaborations, controversies and progress
}

\author{
Sjoerd J. Kluiving ${ }^{1,2, *}$ \& Guus J. Borger ${ }^{2,3}$
}

1 Faculty of Humanities, VU University Amsterdam, De Boelelaan 1105, Room 14A-00, 1081 HV Amsterdam, the Netherlands.

2 Faculty of Earth \& Life Sciences, VU University Amsterdam, De Boelelaan 1085, Room 0-449, 1081 HV Amsterdam, the Netherlands.

3 Department of Social Geography, University of Amsterdam, GPIO, P.0. Box 15.629, 1001 NC Amsterdam, the Netherlands.

* Corresponding author. Email: s.j.kluiving@vu.nl

The history of the Amstel and Vecht rivers in the central part of the Netherlands during the Holocene has been debated for a considerable time (Bos et al., 2009; De Bont, 1994, 2000, 2008; De Bont \& Kleij, 2012; De Gans, 2011; De Gans \& Bunnik, 2011, 2012). Many publications in different disciplines have made their contribution to solve issues such as initiation and cessation of river flow, different and opposing river flow directions, and different chronologies.

This Special Issue results from the symposium 'River development related to the peat exploitation in the area of the Vecht and Amstel rivers, from the Iron Age to $1200 \mathrm{AD}^{\prime}$. The symposium was held on 21 March 2013 at the VU University of Amsterdam as part of the Institute of Geo- and Bioarchaeology (IGBA) seminar series. In this Special Issue it is clear that controversies around the origin and (duration of) stream flow directions and variations in discharge of the rivers Amstel and Vecht still exist and continue to raise questions.

In the first part of this editorial the presented papers from the symposium are summarised. In the second part we give an overview of existing controversies, new research questions and an initial attempt to synthesis of the history of the AmstelVecht fluvial system, focusing on the last 3000 years.

\section{Overview of contributing papers}

Vos et al. describe the landscape history of the 0er-IJ tidal system in the province of Noord-Holland. This tidal system was the outlet of the Amstel-Vecht river system for part of its evolution. The research has led to new insights into a number of key events that have shaped the landscape.

It is confirmed that between 2000 and $1900 \mathrm{BC}$ the proto-0er-IJ estuary south of Assum formed through a marine breakthrough and inlet formation instead of by a gradual migration driven by longshore currents. Furthermore it is argued that the connection between the Flevo lakes and the
Wadden Sea is established much earlier than before, that is, in the Middle Iron Age, while silting up of the Oer-IJ estuary started around $400 \mathrm{BC}$. Geological and archaeological evidence shows that Late Iron Age settlement traces are located on top of Oer-IJ-tidal deposits. Clearly, the Oer-IJ system had been cut off from the sea by a coastal barrier at that time. In the Roman period, this barrier was flooded only during extreme storms, and shell-rich overwash sediments were deposited on the backside of temporary breaches.

Large variations in deepening and widening of the 0er-IJ estuary caused by very significant changes in tidal amplitude and particularly mean high water can only partly be explained by geological processes and archaeological indications. The impact of changing tidal-inlet and -basin configurations on the tidal influence in the region can only be studied by hydrodynamical modelling. This also allows study channel behaviour in the function of subsurface lithological characteristics to be studied.

Another unresolved issue is the onset of Younger Dune formation: the spatial and temporal resolution of our knowledge about dune evolution needs to be improved. Combining OSL dating and geological and archaeological observations appears to be the most promising way forward.

Subsurface information from the new underground metrosystem (Noord/Zuidlijn) has been going on for more than a decade and has resulted in new data on the stratigraphy and development of the Amstel river in the city of Amsterdam (Kranendonk et al., 2015). Research has mainly focused on two locations, Damrak and Rokin, in the centre of Medieval Amsterdam. The Amstel has been of vital importance for the origin and development of the city of Amsterdam. Information on the Holocene evolution of the river, however, is relatively sparse. This project has provided new reconstructions, combining archaeological and geological data, and allowed for the construction of six consecutive landscape phases associated with the development of the Amstel river. 
The course of the present-day Amstel is the result of a complex interaction of processes that started with an early prehistoric tidal gully within the Wormer Member of the Naaldwijk Formation, in which two phases can be distinguished. The nonorganic clastic first phase existed between 4050 and 2000 BC, the more organic second phase lasted from $2000 \mathrm{BC}$ to $1020 \mathrm{BC}$. The channel of the second phase includes Late Neolithic (2400$2000 \mathrm{BC}$ ) occupation debris in its fill, which is partly eroded.

The tidal gully system developed into a prehistoric Amstel river course that was part of the Angstel-Vecht-0er-IJ system (1020-350 BC). This river system meandered through a peatdominated landscape.

A variable history of Amstel river deposition is recorded between $350 \mathrm{BC}$ and $1319 \mathrm{AD}$. At $350 \mathrm{BC}$ the Amstel was getting only episodic water from the Rhine distributaries in the Angstel-Vecht system during times of high discharge (Bos et al., 2009). After $2050 \mathrm{BP}(100 \mathrm{BC})$, the Amstel drained into the IJlake, which gradually eroded the large peat bog in the later Zuiderzee area. This time period is coeval with the closure of the Oer-IJ tidal gully at Castricum near the North Sea coast. The Angstel-Vecht system was abandoned by the Rhine around $1470 \mathrm{BP}$ (480 AD), but the Amstel river continued to drain a peatbog into the expanding Zuiderzee; in this study this phase of river activity is recorded at Rokin to last until 1319 AD.

Late-Medieval storm activities originating from the expanding and opening Zuiderzee forced local authorities to build a dam in the Amstel in the mid-13th century $A D$ to prevent disasters caused by high water events. After intense land reclamation, starting around $1200 \mathrm{AD}$, the meandering Amstel river from Nes to Kalverstraat, which was originally $150 \mathrm{~m}$ wide, became the rather straight $20-50 \mathrm{~m}$ wide tamed, canalised river of today.

De Bont (2015) poses that in the first millennium AD a watershed (the Great Holland Watershed) formed the backbone of the vast Medieval peat lands north and south of the protoAmstel. It is assumed that a secondary watershed, consisting of a mesotrophic unreclaimed peat area, divided the two streams, called northern and southern Amstel, draining in opposite directions. The northern area is assumed to be well drained, while the southern area is viewed as poorly drained. De Bont presents evidence from historiographic and written text documents showing that the Amstel river along a $2 \mathrm{~km}$ stretch running from the 'Omval' to the 'Blauwbrug' has been dug.

Before the Amstel Canal was dug, the people who exploited the western peat ridge along the southern Amstel had to dig a canal. This canal is known as the Boerenwetering. The construction of these artificial waterways fits into the Medieval history of the drainage of larger parts of the peatlands of Holland. De Bont concludes that the Amstel canal was dug between 1063 and $1275 \mathrm{AD}$, and states that the period was long enough to explain the presence of marine clay deposited on the borders of the newly created Amstel river, including the former southern Amstel (De Bont, 2015).
De Gans reports an analysis of cores retrieved from various archives on the origin of the Amstel river in and around Amsterdam. In four new cross-sections he demonstrates that the Amstel course between 'de Omval' and 'Ouderkerk aan de Amstel' shows a double overbank clay layer separated by a peat layer. Also in the northern part within the presumed dug canal part of the Amstel (De Bont, 2015), near the Toronto bridge, as well as at the Dam, a similar stratigraphy is observed with an upper and a lower overbank clay layer with a peat layer in between.

The lower overbank clay layer is dated to be deposited between $3000 \mathrm{BP}$ to $1000 \mathrm{AD}$, and contains pollen derived from the Rhine river. The peat layer in between the two clay layers indicates a decrease in fluvial overbank sedimentation. The reduced clay sedimentation may be due to a shift in discharge to the Vecht, the infilling of existing lakes such as the Watergraafsmeer, which act as sediment traps, and also to the construction of a dam in 1122 AD near Wijk bij Duurstede. The initiation of the peat layer may be (indirectly) caused by storms forcing incursions of water from the Zuiderzee, the introduction of tides in the Zuiderzee around $800 \mathrm{AD}$, and the subsidence of the land due to peat exploitation activities. The uppermost clay layer is interpreted to be deposited as a result of storm surges in the 12 th century.

The presumed canal between the Blauwbrug and De 0mval as well as the two northern and southern Amstel courses (De Bont, 2015) is refuted by De Gans, with the following arguments: (i) the overbank clay layer south of the disputed stretch proves the presence of a (single) north-flowing Amstel river before $1000 \mathrm{AD}$, (ii) the presence of Abies and Picea pollen from the Beurs core (presumed northern Amstel) suggests a Rhine provenance of the Amstel sediments, (iii) eutrophic peat along the river does not fit with the suggestion that the southern Amstel was a minor river in a peatland area, and (iv) the dimensions (width and depth) of the river sediment body at the disputed river stretch do not fit the man-made hypotheses.

Buitelaar and Borger present an overview of the habitation history in the Early Middle Ages in the landscape of the Vecht area based on historical accounts. Next to that, landscape changes since $1050 \mathrm{AD}$ are described as a consequence of the systematic exploitation of the vast peat surface in the area. Two main lines of historical reconstruction are reported. First, since the Flevomeer/Almeer had been indicated as stagnant around the middle of the 8th century $\mathrm{AD}$, it has to be concluded that the tidal currents of the Vlie only since then could have affected the water level in the inland lake area. Second, it has to be assumed that the territory of the Van Amstel dynasty ('Heren van Amstel') around $1200 \mathrm{AD}$ was already protected on the north side by a dike against the water of the Zuiderzee. This is because of the recorded fact of the 'doorsteken' (breaching) of the agger Amestelle during acts of war in the year 1204 AD. The Van Amstel dynasty was a major lordly dynasty in the 
Medieval Netherlands that held the 'heerlijkheid' of Amstelland (the area around the Amstel).

The importance of the waterway formed by the Rhine-Vecht system for Romans 2000 years ago is indicated by the basalt study of Linthout (2015). From the Kotterbos site in Flevoland, a solitary unprocessed basalt stone (basanite, $26 \mathrm{~cm}$ ) has been found at a $69 \mathrm{AD}$ dated Roman site. Since this rock does not occur naturally in the Netherlands, the Romans must have imported the stone. The geoarchaeological questions are: how did the stone arrive at Kottersbos, and can provenance studies determine if the stone can be attributed to one of the two established source sites for Limes basalts, Rolandsbogen and Erpeler Ley along the Rhine, or elsewhere? Combining macroscopic and microscopic petrographical and morphological analyses it is determined that the Kotterbos basalt is similar to basalts from the Limes in Vleuten-De Meern and Utrecht, and it is close to the Central European Volcanic Province (CEVP). Through geochemical analysis it can be further specified that the Kotterbos basalt can be found amongst those CEVP basalt analyses that comply with all compositional criteria and the respective spread of each of the 13-23 fingerprint criteria of the group of high $\mathrm{Mg}$ 'number' and low $\mathrm{TiO}_{2}$ basalts.

These results, combined with archaeological argumentation, show that many large columnar basalt blocks from other Dutch archaeological sites were transported from Rolandsbogen to the northern Limes. Archaeological questions remain as to why the unusual size of the Kotterbos stone, not intended for construction purposes, was brought here from Rolandsbogen. It is speculated that sailors might have taken these loose cobbles of Rolandsbogen basalt aboard for some reason of their own. However, no proof for the presence of a ship has yet been found (van Heeringen et al., 2014). The archaeological and geological indications for the Kotterbos site allow a relative dating for the arrival of the basalt stone between around 60 and $100 \mathrm{AD}$.

Subsurface conditions had a profound effect on both the landscape development and the expansion of the city of Amsterdam from the Middle Ages onwards (Schokker et al., 2015). The last published geological map of Amsterdam dates from more than a century ago, so the 3D model is a welcome contribution to the subsurface knowledge base of the city of Amsterdam. The subsurface characterisation based on DGM and GeoTOP modelling results in a number of outcomes: (i) the Amstel river follows a tidal channel on part of its course (cf. De Gans, 2015; Kranendonk et al., 2015), (ii) the potential future extractions of coarse sand and gravels are facilitated by the mapping of the ice-pushed deposits underneath the city surface and (iii) the extent of the so-called Boerenzand layer, one of the four foundation levels beneath Amsterdam, appears to be more discontinuous and seems to be related to tidal channels in the lower tidal deposits. The clayey sand reflects a tidal flat area rather than channel facies.

The methodological paper by Schokker et al. gives useful background information for the papers of Kranendonk et al.
(2015) and De Gans (2015), specifically concerning the confirmation of the tidal channel underlying the Amstel river. Furthermore, the information, the maps, as well as the available online digital resources are of great value to the earth scientific and general community.

\section{Discussion}

With the results of the papers in this Special Issue it can be confirmed that the Amstel had a prehistoric origin in a tidal channel environment (De Gans, 2015; Kranendonk et al., 2015; Vos et al., 2015; Schokker et al., 2015), with convincing evidence of Bell Beaker civilisation at its border (Kranendonk et al., 2015). Because of the higher erodibility of the clayey sand deposits of the channel fill as suggested by Schokker et al. (2015), 3000 years ago the Amstel river could develop in the eroded gully of this palaeo-valley, following the older course of the tidal channel.

For the discussion in this editorial a unified terminology is needed for the 'Vecht'. Through an avulsion at Utrecht part of the Rhine waterflow was diverted in a northern direction. Here we propose to call this river part the 'northern Rhine branch'. At first the northern Rhine branch followed the course of the Angstel/Amstel, draining into the North Sea via the Oer-IJ system. Afterwards, downstream from Loenen, the river started to flow in a more northern direction, and drained via the lower course of the current Vecht in the Lake Flevo and, subsequently, into the Wadden Sea.

What consequences does the supposed early closure of the Oer-IJ estuary (Vos et al., 2015) have for the location choice of the Castellum Velsen protecting a Roman naval fleet base? Vos et al. argue that the 0er-IJ between Velsen and Amsterdam remained open and that the Roman harbour at Velsen retained a good connection with the Oude Rijn, the Roman border (Limes) at $50 \mathrm{AD}$, through the Amstel and Vecht rivers. The early closure in $350 \mathrm{BC}$ of the Oer-IJ by Vos et al. contradicts the Amstel draining into the North Sea via the 0er-IJ until 220-400 AD (De Gans, 2015).

The Velsen layer as well as underlying strata up to the top of the Boxtel Fomation have been removed by the 0er-IJ in a southern direction although it is uncertain to what lateral extent (Kranendonk et al., 2015). In layer R1.2, in the basal part of a tidal gully, archaeological materials dating from the Bell Beaker (c. 2400-2000 BC) have been retrieved. It is striking to note that the start of the younger tidal gully (R1.2) around 2000 $\mathrm{BC}$ at Rokin (Kranendonk et al., 2015) corresponds with the date of the associated ingression of the 0er-IJ at 1900-2000 BC (Vos et al., 2015). The Bell Beaker finds are interpreted as having been present at the margin of the oldest tidal gully at the Rokin (R1.1), in association with cultural remains (Kranendonk et al., 2015), which may have been present in a landscape such as shown on the paleo map of 2750 BC in Vos et al. (2015). 
This suggests that Late Neolithic habitation might have been common along this older gully system and has been eroded by the 0er-IJ tidal gully that used the old paleo tidal gully valley (Map 1500 BC, Vos et al., 2015).

Based on the archaeological findings of the Bell Beaker culture, the second tidal gully must have been active until around 2000 BC, and potentially even until 1020 BC (3000 BP). The later date is entirely derived from correlations with other publications (Bos et al., 2009). Apparently this type of tidal gullies also occurs elsewhere in the subsurface of Amsterdam (Kranendonk et al., 2015). The brackish to freshwater stream deposit points to a stable landscape in which peat could grow and which was suitable for habitation. The original location of the BellBeaker traces are potentially a point-bar system next to a gully, such as shown on the palaeogeographical map of 2750 BC (Vos et al., 2015).

The oldest datable activity of the prehistoric Amstel (R2/D2) postdates the start of flow of this river $(1020 \mathrm{BC})$. If we assume that the reason for the shut-down of the connection with the Angstel-Vecht system has to be found upstream, then the prehistoric Amstel gradually transforms into a river that should have had a specific width and depth with an increase in organic material in an emerging peat landscape.

After the 0er-IJ had virtually lost its tidal energy in the system, the flow of water in the former river must have come to a complete standstill. Only the precipitation surplus from the peat landscape would be discharged afterwards, although the size of this catchment is unknown. Clearly it was a marshy, poorly drained area, in which the deposition of organic material was a very slow process. Only after the tidal effects induced by the Vlie tidal channel had become strong enough in the Almeer was the water system in the former Amstel river re-activated.

The emergence of the Zuiderzee is caused by erosion due to storm events ignited by increasing tidal energy in the system. Kranendonk et al. (2015) report from the key locations of Damrak and Rokin that the transition between D3/D4 units corresponds with the Dam construction in $1264 \mathrm{AD}$. The base of $\mathrm{R} 4$ shows considerable erosive processes taking place. The overlying R4 deposits indicate the presence of freshwater. However, in unit D4 brackish influence is clearly demonstrated. In both units R4 and D4 only traces of 14th century storm deposits have been preserved, testifying to the high-energy 13th century events that eventually led to the construction of the dam. This also implies that the Vlie tidal inlet was connected to the south, causing brackish water to flow into the Amstel at the time of the dam's construction. The lower unit D3/R3, interpreted to be deposited between $350 \mathrm{BC}$ and $1264 \mathrm{AD}$, also shows clear brackish influence, suggesting an open connection to either the Oer-IJ or the Vlie channel, the only sources for brackish water in the Amstel river. Does this finding support an earlier opening of the Zuiderzee than the previously assumed 1200 or $800 \mathrm{AD}$ or is the brackish influence in the
Amstel in the lower part of units R3/D3 caused by marine overflow of the barrier at the 0er-IJ channel? The lower parts of the coastal barrier at Castricum were subjected to overwash deposits in the 0er-IJ system until the 2nd century $\mathrm{AD}$ (Vos et al., 2015).

With the growth of the Flevo lakes/Almeer/Zuiderzee water area, the water dynamics at the mouth of the Amstel have been activated. This may have caused erosion, but it remained dominantly a freshwater environment since there was a 'long waterdischarge route through the Flevo lakes to the Wadden Sea' (Vos et al., 2015). The brackish influence noted by Kranendonk et al. (2015) in the R3/D3 unit suggests that this freshwater influence was alternating with storm episodes or high-energy events that most likely were derived from the Wadden Sea. Potentially until the 2 nd century $\mathrm{AD}$ these brackish conditions might have originated from the 0er-IJ system, after the complete shutdown of the 0er-IJ system brackish influence must have been originating from the Vlie channel and associated Flevo lakes. It remains open to future research to test this hypothesis. The conclusion that when the 0er-IJ system was shut down, the Vlie tidal channel opened at $350 \mathrm{BC}$ (Vos et al., 2015) appears to be in contrast with 'stagnant' water of the Flevo Lake during the travels of Bonifatius in the 8th century AD (Buitelaar \& Borger, 2015).

De Gans concludes that the construction of the dam at Wijk bij Duurstede in 1122 AD caused the Kromme Rijn as well as the Vecht/Angstel/Amstel system to be cut off from the Rhine system. This contrasts with Bos et al. (2009), who has made it clear that the connection between Rhine and Amstel must have been cut off before this.

Did De Gans (2015) prove convincingly that the Amstel part between the Blauwbrug and the Omval has a natural cause? De Bont (2015) approaches the peat exploitation in a model study with a spatial component and considers the habitation and settlement history of the peat lands. It was concluded that there was a dug part of the Amstel between Blauwbrug and Omval is based on this model. De Gans (2015) challenges the dug Amstel hypothesis with a number of geological arguments relating to: (i) an upper overbank clay layer, (ii) pollen evidence, (iii) eutrophic peat and (iv) dimensions. De Gans (2015) acknowledges that peat started to grow in the river Amstel around 1000 AD. Possibly humans have cleaned up and slightly straightened parts of the Amstel course, but in essence the Amstel is a natural stream (De Gans, 2015). Also, the hypothesis of a northern and a southern Amstel put forward by De Bont does not correspond with the paper by Kranendonk et al. (2015), who describe a continuous Amstel sedimentation with sometimes brackish influence.

It is still unclear if the Amstel river was straightened by human activities between the 11th and 13th centuries in an existing river course or that the digging took place in a completely filled-up river. Future research on the overbank clay and peat layer next to the disputed stretch might resolve 
2015. The Amstel river has a complex, intertwined development of natural and human-induced processes. To address the Vecht-Amstel history an interdisciplinary research approach will be needed, with a combined historical, geographical, archaeological and geological methodology.

Considering the results presented in all seven papers it appears that there is a relationship between four processes that have acted more or less simultaneously in the Amstel-Vecht, Oer-IJ- Flevo Lake region, and over which there is disagreement on the timing: (i) the closure of the 0er-IJ tidal system ranges between $350 \mathrm{BC}$ and 220-400 AD, (ii) the reduced water flow from the northern Rhine branch (480 AD?), (iii) the shifting of the drainage direction of the northern Rhine branch from a western to a northern drainage direction (350 BC?) and (iv) the emergence of the connection between the Flevo lakes and the Vlie channel (Wadden Sea); the latter dates ranging between $350 \mathrm{BC}$ and $800 \mathrm{AD}$.

If there is indeed a relationship between these four processes then the question arises as to cause and effect relations. Does that give support to the conclusion of De Gans that the Amstel drained until 220-400 AD via the Oer-IJ into the North Sea? Does it support the thesis of Van Dinter (2013) that from the end of the 3rd or start of the 4th century AD onwards peat has developed on the lower parts of point bar deposits of the Vecht river?

The discussion in this editorial, the editorial process as well as the content of the papers in 2015 have shown how complex and highly interesting attempts to combine disciplines can be. The combined set of papers includes geological (Linthout, 2015) and historical (De Bont, 2015; Buitelaar \& Borger, 2015) records, as well as geological modelling (Schokker et al., 2015). In the future, the controversies illustrated in this editorial are to be addressed through interdisciplinary collaborations, as suggested by De Gans (2015) and demonstrated by Kranendonk et al. (2015) and Vos et al. (2015).

\section{References}

Bos, I.J., Feiken, H., Bunnik, F. \& Schokker, J., 2009. Influence of organics and clastic lake fills on distributary channel processes in the distal Rhine-Meuse delta (The Netherlands). Palaeogeography, Palaeoclimatology, Palaeoecology 284: 335-374.

Buitelaar, A.L.P. \& Borger, G.J., 2015. Landscape development and settlement history of the Vecht area (722-1122). Netherlands Journal of Geosciences Geologie en Mijnbouw 94 (4): 375-385.

De Bont, C., 1994. Reclamation patterns of peat areas in the Netherlands as a mirror of the mediaeval mind. In: Bethemont, J. (ed.): L'avenir des paysagesrurauxeuropéens entre gestion des héritages et dynamique du changement. Conférenceeuropéenne permanente pourl'étude du paysage rural; colloque de Lyon, 9-13 juin 1992. UniversitéLumière Lyon 2/Université Jean Moulin Lyon
3 (lyon): 57-64. (In 1994 also published in: Wageningen Studies in Historical Geography 2: 61-68).

De Bont, C., 2000. Delft's Water; two thousand years of habitation and water management in and around Delft. Zutphen. IHE Delft, Walburgpers Zutphen.

De Bont, C., 2008. Vergeten land; ontginning, bewoning en waterbeheer in de Westnederlandse veengebieden (800-1350). Dissertation. Wageningen University (Wageningen) (in 2009 also published as: Alterra Scientific Contributions, 27)

De Bont, C., 2015. Digging the river: the historical geography of the Amstel area (800-1275 AD). Netherlands Journal of Geosciences — Geologie en Mijnbouw 94 (4): 353-360, doi:10.1017/njg.2014.42

De Bont, C. \& Kleij, P., 2012. Tussen Oer-IJ en Bamestra; het Zaanse veenmoeras en zijn eerste bewoners vanaf de prehistorie tot ca. 900. In: Beukers, E. \& C. van Sijl (eds): De geschiedenis van de Zaanstreek, part 1, 10-23. WB00KS, Zwolle.

De Gans, W., 2011. De bodem onder Amsterdam. Een geologische stadswandeling. TN0-Geologische Dienst Nederland, Utrecht, $70 \mathrm{pp}$.

De Gans, W., 2015. The geology of the Amstel river in Amsterdam (Netherlands): Man versus nature. Netherlands Journal of Geosciences - Geologie en Mijnbouw 94 (4): 361-373, doi:10.1017/njg.2014.41

De Gans, W. \& Bunnik, F., 2011. De loop van de Amstel in Amsterdam. Grondboor en Hamer 65 (2): 42-49.

De Gans, W. \& Bunnik, F., 2012. Ruigoord en het Oer IJ. Grondboor en Hamer 66 (6): 462-468

Kranendonk, P., Kluiving, S.J., \& Troelstra, S.R., 2015. Chrono- and archaeostratigraphy and development of the River Amstel: results of the North/South underground line excavations, Amsterdam, the Netherlands. Netherlands Journal of Geosciences - Geologie en Mijnbouw 94 (4): 333352, doi:10.1017/njg.2014.38

Linthout, K., 2015. Provenance of the Roman basalt stone at Kotterbos (Lelystad, the Netherlands): A geoarchaeological study based on petrographic and geochemical analysis, and comparison with a synthesis of basalt stones along the northern Limes. Netherlands Journal of Geosciences - Geologie en Mijnbouw 94 (4): 387-397, http://dx.doi.org/10.1017/njg.2014.45

Schokker, J., Bakker, M., Dubelaar, W., Dambrink, R. \& Harting, R., 2015. 3D subsurface modelling reveals the shallow geology of Amsterdam. Netherlands Journal of Geosciences - Geologie en Mijnbouw 94 (4): 387-397.

Van Dinter, M., 2013. The Roman Limes in the Netherlands: how a delta landscape determined the location of the military structures. Netherlands Journal of Geosciences - Geologie en Mijnbouw 92(1): 11-32.

Van Heeringen, R., Hessing, W.A.M., Kooistra, L.I., Lange, S., Quadflieg, B.I., Schrijvers, R. \& Weerheijm, W., 2014. Archeologisch landschapsonderzoek in het kader van het project kwaliteitsverbetering Kotterbos (locatie Natuurboulevard) in de gemeente Lelystad, provincie Flevoland. Menselijke activiteit in natte landschappen in de Steentijd en de (Vroeg-) Romeinse tijd. Rapportnummer: V1132, Deel A, Vestigia Archeologie \& Cultuurhistorie (Amersfoort): $160 \mathrm{pp}$

Vos, P., Koning, J. de \& Eerden, R. Van, 2015. Landscape history of the OerIJ tidal system, Noord-Holland (The Netherlands). Netherlands Journal of Geosciences - Geologie en Mijnbouw 94 (4): 295-332. 